\title{
Biosynthesized Silver Nanoparticles (AgNPs) from Trapa natans Peel Extract Exhibits Anti-Metastasis and Anti-Biofilm Potentials
}

\author{
Adyasa Samantaray, Debasish Pradhan*, Bandana Behera \\ University Department of Pharmaceutical Sciences, Utkal University, Bhubaneswar, Odisha, INDIA.
}

\begin{abstract}
Background: This study deals with the anti-metastasis and anti-biofilm activities using silver nanoparticles (AgNPs) against human breast cancer cells (MCF-7) via in vitro methods. Different studies have been reported that biofilms formed by Klebsiella pneumoniae, Escherichia coli and Staphylococcus aureus are resistance to most of the recently used antibiotics due to MDR effect. Materials and methods: The characterization of biosynthesized particles was done by UV-vis spectroscopy, FTIR, SEM and XRD techniques. Cytotoxicity analysis was done by MTT assay and Neutral Red Uptake (NRU) assay. Anti-biofilm activity was carried out by using the bacterial strains of Klebsiella pneumoniae, Escherichia coli and Staphylococcus aureus respectively. Results: AgNPs exhibit strong absorption peak in the $420-500 \mathrm{~nm}$ range due to Surface Plasmon Resonance in UV- Vis spectroscopy. In FTIR analysis, we found phenol and alcohol compounds (at $3447 \mathrm{~cm}^{-1}$ ), carbonyl groups (at $1631 \mathrm{~cm}^{-1}$ ), alcoholic groups (at $1384 \mathrm{~cm}^{-1}$ ) and polysaccharides (at $1093 \mathrm{~cm}^{-1}$ ). In XRD that AgNPs formed were highly crystalline in nature. In SEM the diameter of AgNPs ranges from 30-90 nm and TEM depicts the size of AgNPs to be $15 \pm 2 \mathrm{~nm}$. T. natans-AgNPs exhibits strong cytotoxic activity against MCF-7 breast cancer cell line. Conclusion: The presence of different bioactive molecules in T.natans shows that, green synthesized AgNPs significantly inhibited proliferation of MCF-7 breast cancer cells by inducing apoptosis as well as antibiofilm activity using different bacterial colonies.For the very first time we are reporting the anticancer drugs repositioned as a potential antibiofilm agent in the Klebsiella pneumoniae, Escherichia coli and Staphylococcus aureus organisms.
\end{abstract}

Key words: Trapa natans, Silver Nanoparticles (AgNPs),Human Breast Cancer Cells (MCF-7), Anti-biofilm, Anti-metastasis, Cytotoxicity.

\section{INTRODUCTION}

The use of medicinal plants as a source of relief from diseases can be traced back over five millennia to the written records of the early civilizations in India for a long period of time. Plants are the valuable source of natural products for the maintenance of human health, particularly in the last decade, with more extensive studies on natural therapies. According to World Health Organization, medicinal plants are the best source and safest way to acquire a range of drugs. Approximately $80 \%$ of individuals in developed countries use traditional medicines with compounds derived from medicinal plants. Research in anti-cancer activity of higher plants in India started seriously in the sixties and gained momentum in the seventies. ${ }^{1}$ Medicinal herbs constitute indispensable components of the traditional medicines practiced worldwide due to low cost, easy access and ancestral experience. ${ }^{2}$

According to the World Health Organization, cancer is a leading cause of death worldwide, and the number of deaths is projected to continuously rise in the coming years. ${ }^{3}$ Worldwide, the most commonly diagnosed tumor types are lung, breast, and
Submission Date: 24-02-2021; Revision Date: 6-05-2021; Accepted Date: 02-07-2021

DOI: 10.5530/ijper.55.3.153 Correspondence: Dr. Debasish Pradhan University Department of Pharmaceutical Sciences, Utkal University,

Bhubaneswar, Odisha, India. Phone no: +919861137772 Email: deba_udps@yahoo. co.in

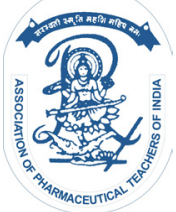

www.ijper.org 
colorectal cancer. ${ }^{4}$ Cancers can be developed in one of three ways, including incorrect diet, genetic predisposition, and by the environment. Chemotherapy is usually given in repeated cycles of treatment. Natural products have an important role as anticancer agents, and many of the cytotoxic drugs used clinically today are derived from plants. ${ }^{5}$

The use of silver and silver salts is extremely old as human civilization but the manufacture of silver nanoparticles (AgNPs) has been recently recognized. They are particularly used in medicine as antibacterial, antifungal and antioxidants and in agriculture. It is demonstrated that AgNPs stops the growth and replication of many bacteria such as Bacillus cereus, Citrobacter koseri, Staphylococcus aureus, Salmonella typhii, Vibrio parahaemolyticus, Escherichia coli, Klebsiella pneumoniae, Pseudomonas aeruginosa, and fungus Candida albicans by binding $\mathrm{Ag} / \mathrm{Ag}^{+}$ to the biomolecules present in the microbial cells. NPs have attracted increasing interest from each branch of medicine in their ability to deliver drugs in the optimal dosage range, often resulting in enhanced therapeutic efficiency of the drugs, weakened side effects and improved patient compliance. ${ }^{6}$ In recent days green synthesis have received a huge attention due to its eco-friendly therapeutic approaches and advantages such as economic viability, less waste generation and simple in process.

In this study we used a simple green process to synthesize AgNPs using Trapa natans peel extract. The Trapa natans extract has been used as an efficient reducing and capping agent. The extract contains several polyphenolic compounds that possess a wide range of biological activities, including antioxidant, anticancer, antibacterial, antifungal effects, etc. Trapa natans peel extract derived on MCF-7 cells has not been established practically so far. From the treatment options for breast cancer, chemotherapy and radiation are plagued by side effects that include lumps in breast, hair loss, fatigue, bleeding and infections, whereas other treatments are effective in some patients only. For these reasons, more effective alternative cancer therapeutic compounds with minimal side effects are desperately being sought.

\section{MATERIALS AND METHODS}

\section{Preparation of plant extract}

The fresh Trapa natans (water chestnut) plant fruits were purchased from a local market in Balasore, Odisha, India and washed using distilled water to remove impurities. The outer hard cover peel was removed from the fruit and air dried. The dried samples were crushed ground into powder using a mortar/pestle and stored in airtight bottles. Thereafter, $5 \mathrm{gms}$ of $T$. natans powder was added to $100 \mathrm{ml}$ of distilled water in steam bath for $15-20$ mins at $80^{\circ} \mathrm{C}$. The extract obtained was cooled to room temperature and filtered through Whatman No.1 filter paper. The solution was treated as source extract and was stored for further analysis.

\section{Biosynthesis of silver nanoparticles}

For preparation of AgNPs, $10 \mathrm{~mL}$ of the prepared $T$. natans peel extract was added drop wise to $90 \mathrm{~mL}$ of $0.1 \mathrm{mM}$ silver nitrate $\left(\mathrm{AgNO}_{3}\right)$ aqueous solution. The mixture obtained was then stored under dark condition in room temperature to avoid auto-oxidation for $24 \mathrm{hr}$ and the color of the solution was then changed to yellowish-brown (indicate the formation of NPs). The solution was then transferred to round bottom flask and heated at $90^{\circ} \mathrm{C}$ with continuous stirring up to $15 \mathrm{mins}$. Solution was centrifuged at $900 \mathrm{rpm}$ in room temperature and the pellet form of silver nanoparticles was then dried up at $60^{\circ} \mathrm{C}$ in hot air oven (forms blackish powder) and was finally diluted in $1 \%$ dimethyl sulfoxide (DMSO). The biosynthesized AgNPs was then stored and employed for further characterization using UV-Vis spectroscopy, FTIR, SEM and TEM techniques, etc.

\section{Characterization of biosynthesized silver nanoparticles}

\section{UV-Vis Spectral Analysis}

Spectral analyses of synthesized NPs at different reaction concentration were observed. The absorption spectra of the mixture were recorded with a Shimadzu UV-visible spectrophotometer (UV-1800) from 200 to $800 \mathrm{~nm}$ and resolution of $1 \mathrm{~nm}$.

\section{FTIR Spectroscopy}

Fourier transform infrared spectroscopy (FTIR) was utilized to identify the presence of possible biomolecules of T. natans extract involved in formation and stabilization of AGNPs. For this, purified T. natans AgNPs (in powder form) was grinded manually with $\mathrm{KBr}$ pellets and then used for FTIR measurement. The FTIR of particles were recorded at a wavelength of $400-4000 \mathrm{~cm}^{-1}$ using FTIR, Shimadzu.

\section{XRD Analysis}

The phase purity and particle size of T. natans AgNPs were determined by using the X-ray diffractometer (XRD-Bruker AXS). The X-ray diffraction (XRD) pattern 
was carried out at a current of $30 \mathrm{~mA}$ and voltage of $40 \mathrm{kV}$ with $\mathrm{Cu} \mathrm{K} \alpha$ radiation $(1.5405 \AA)$.

\section{Microscopy Study}

Morphological analysis of T. natans AgNPs was conducted by using transmission electron microscopy (TEM; HITACHI H-7650, Tokyo, Japan) at voltage $120 \mathrm{kV}$. To observe the surface morphology and size distribution of AgNPs, Scanning electron microscope is used as the most powerful diagnostic devices. For SEM observation, the sample was coated with thin layer of platinum and SEM image has been taken by SEM (Philips XL-30) at $26 \mathrm{KV}$.

\section{Determination of in vitro Anticancer Activity of Synthesized AgNPs \\ Cell Culture}

Breast cancer cell line (MCF-7) was obtained from the National Centre for Cell Science (NCCS), Pune, India. The MCF-7 cells were freshly cultivated as monolayer in Dulbecco's Modified Eagles's Medium (DMEM), supplemented with 10\% FBS, 1\% glutamine, and 100 $\mathrm{U} / \mathrm{mL}$ penicillin/streptomycin and incubated at $37^{\circ} \mathrm{C}$ in $5 \% \mathrm{CO}_{2}$ atmosphere.

\section{Cytotoxic assay}

The cytotoxic effects of T. natans AgNPs on MCF-7 cell line was measured using MTT assay [3-(4,5-dimethylthiazol-2-yl) -2,5-diphenyltetrazolium]. The MCF-7 cells were seeded into 96-well plates and in DMEM supplemented with $10 \% \mathrm{FBS}$ for $24 \mathrm{hr}$ at $37^{\circ} \mathrm{C}$ in $5 \% \mathrm{CO}_{2}$ incubator. After $24 \mathrm{~h}$ of the culture, cells were treated with different doses of AgNPs in the growth medium for another $24 \mathrm{hr}$ under the same culture conditions. Wells with only cells (media as a vehicle only) without nanoparticles were considered as negative control, whereas wells with only MTT, considered as positive control. Cell viability was determined by adding MTT dye (100 $\mu \mathrm{l}$ of $0.1 \mathrm{mg} / \mathrm{mL}$ stock) to respective well and incubated for $4 \mathrm{hr}$ at $37^{\circ} \mathrm{C}$ with $5 \% \mathrm{CO}_{2}$ in the dark. 3-(4,5-dimethylthiazol-2-yl)-2,5-diphenyltetrazolium bromide (MTT) a yellow tetrazole reduced to purple formazan in living cells by the action of $\operatorname{NAD}(\mathrm{P})$ H-dependent cellular oxidoreductase enzymes. The insoluble formazan crystals were dissolved in isopropanol for $1 \mathrm{hr}$ at $37^{\circ} \mathrm{C}$, into a colored solution. The quantification of formazan was determined by measuring absorbance at $570 \mathrm{~nm}$. The degree of light absorption depends on the solvent. ${ }^{7,8}$ The percentage of cell viability was calculated according to the following formula. ${ }^{9}$
$\%$ cell viability $=([\mathrm{OD}$ treated cell $-\mathrm{OD}$ blank $] /[\mathrm{OD}$ control cell - OD blank]) $\times 100$.

\section{Neutral Red Uptake Cytotoxicity Assay}

MCF-7 cells were treated with $1-100 \mu \mathrm{g} / \mathrm{ml}$ T.natansAgNPs for $24 \mathrm{~h}$. The cells were then washed with PBS twice and incubated in with $50 \mu \mathrm{g} / \mathrm{ml}$ of neutral red containing medium for $3 \mathrm{~h}$. The cells were washed off with a solution $\left(1 \% \mathrm{CaCl}_{2}\right.$ and $0.5 \%$ formaldehyde). The dye was extracted in $1 \%$ acetic acid and 50\% ethanol mixture. The plates were measured at $550 \mathrm{~nm}$. The results were expressed in percentage of control.

\section{Measurement of ROS}

Intracellular reactive oxygen species (ROS) levels were identified by the fluorescent probe 2', 7'-dichlorofluorescein diacetate (DCFH2-DA) (Sigma). In $1 \mathrm{~mL}$ stock $10 \mu \mathrm{M}$ prepared in DMSO was added to each plate and incubated for $30 \mathrm{~min}$ at $37^{\circ} \mathrm{C}$. Samples were then measured with a fluorescent plate reader (Biotek- FL $\times$ 800). DCF fluorescence was measures at $485 \mathrm{~nm}$ of excitation and $520 \mathrm{~nm}$ of emissions. ROS production was determined from an $\mathrm{H} 2 \mathrm{O} 2$ standard curve $(10-200 \mathrm{nM}) .{ }^{10}$

\section{Apoptosis Assay}

The apoptosis/necrosis induced by T. natans AgNPs in MCF-7 cells was analysed using Annexin-V- VFITC/ propidium iodide (PI) apoptosis detection kit (SigmaAldrich Co.). In brief, cells treated with T. natans AgNPs for 12,24 , or $48 \mathrm{~h}$ were harvested, washed with PBS twice, resuspended in binding buffer and incubated with Annexin V-FITC and propidium iodide solutions in the dark for $30 \mathrm{~min}$ at room temperature. Apoptosis was determined by flow cytometry.

\section{Determination of Anti-Biofilm Activity of Synthesized AgNPs}

The anti-biofilm activity of biosynthesized $T$. natans AgNPs was observed with or without T. natans AgNPsagainst the biofilm producing standard bacterial strains. Biofilm generation of the concerned pathogenic bacteria was carried out using the tissue culture plate (TCP) technique as explained by Balasamyet al. ${ }^{11}$ which is commonly used worldwide and is considered as standard test for detection of biofilm production with some modifications. The bacterial strains of Klebsiella pneumoniae, Escherichia coli and Staphylococcus aureus, were grown on blood agar plate for overnight at $37^{\circ} \mathrm{C}$ and the next day a single colony of all bacteria was inoculated into different conical flasks containing the $100 \mathrm{~mL}$ TSB at $37^{\circ} \mathrm{C}$ for $6-7 \mathrm{hr}$ with shaking at $100 \mathrm{rpm}$ until to obtain approximately $2.5 \times 10^{8} \mathrm{CFUs} / \mathrm{mL}$. These bacterial inoculums were further diluted (1:100) with 
fresh TSB medium to approximately $10^{6} \mathrm{CFUs} / \mathrm{mL}$ and transferred it to 96 wells flat bottom TCPs and incubated at $37^{\circ} \mathrm{C}$ for overnight. After completion of the incubation, the old culture medium was changed with a fresh TSB medium including different concentrations of T. natans AgNPs (6.5-100 $\mu \mathrm{g} / \mathrm{mL}$ ), without disrupting the biofilm. Samples with AgNPs were further incubated at $37^{\circ} \mathrm{C}$ for $24 \mathrm{~h}$. The medium was then discarded; each well were washed gently two times with sterile $1 \mathrm{x}$ Phosphate buffer saline (PBS) to eliminate the planktonic state or free floating bacteria and dried it at room temperature for $20 \mathrm{~min}$. $0.1 \%$ crystal violet solution was added to each well for $15 \mathrm{~min}$ to stain the biofilms. The excess stain was eliminated by washing three times with sterile 1\% PBS, and dried at room temperature for $30 \mathrm{~min}$. $100 \mathrm{~mL}$ of $95 \%$ ethanol was then added to each well. The optical density (OD) of stained acquired biofilm was observed at wavelength $595 \mathrm{~nm}$ by a micro ELISA reader. Experiments were repeated in triplicate. Average OD values of sterile medium were measured and deducted from the all test values. ${ }^{12}$ The Optical Density of the sample was converted to biofilm inhibition percentage and calculated as follows:

$$
\begin{aligned}
\text { Percentage of Biofilm }= & \text { OD of the test } / \\
& \text { OD of the control } \times 100
\end{aligned}
$$

\section{Statistical Analysis}

The data obtained from each experiment were presented as mean \pm standard error values. Difference between the control and the test were evaluated using the Student's $t$-test or otherwise stated in their respective legends. In this study, One-way ANOVA (post-hoc Tukey test) was used to analysis of differences between groups. Results with $P<0.05$ were considered to be statistically significant. The half maximal inhibitory concentration $\left(\mathrm{IC}_{50}\right.$ ) value was calculated by 4-parameter curve fitting using the Sigma Plot program (version 12, SPSS, Inc., Chicago).

\section{RESULTS AND DISCUSSION}

\section{Characterization of AgNPs by UV-visible spectroscopy}

UV-vis spectroscopy is one of the most widely used techniques to characterization of silver nanoparticles in the size range of 2-100 $\mathrm{nm}$. It is well known that AgNPs exhibit strong absorption peak in the $420-500 \mathrm{~nm}$ range due to the collective oscillation of free conduction band electrons in particles, phenomenon known as the Surface Plasmon Resonance. The AgNPs synthesis was initially identified by appearance of yellowish-brown color in the reaction mixture. The SPR band centered at $420 \mathrm{~nm}$ confirms the formation of $\mathrm{Ag}$ nanoparticles (Figure 1). While, the UV-vis spectra of T. natans extract didn't show any peaks in the visible range. It was considered, as the incubation time of silver nitrate solution with the plant extract increases the intensity of the absorption peaks also increased progressively, which indicated the increased reduction of silver nitrate by T.natans extract solution and increased AgNPs concentration in reaction mixture.

\section{FTIR Analysis}

The FTIR spectrum of bio-synthesizedAgNPs was used to identify the functional groups present on the surface of the particles. As shown in Figure 2, the broad peak centered around $3447 \mathrm{~cm}^{-1}$ represent $\mathrm{O}-\mathrm{H}$ stretching vibration in phenols and alcohols compounds. ${ }^{13}$ The distinct peak located at $1631 \mathrm{~cm}^{-1}$ represent the $\mathrm{C}=\mathrm{O}$ stretching vibrations in carbonyl groups of proteins. ${ }^{14}$ The peaks at $1384 \mathrm{~cm}^{-1}$ corresponds to $\mathrm{C}=\mathrm{O}$ stretching of the alcoholic groups. ${ }^{13}$ Another peak emerged at $1093 \mathrm{~cm}^{-1}$ attributed to $\mathrm{C}-\mathrm{O}-\mathrm{C}$ stretching vibrations of polysaccharides. ${ }^{15}$ Hence, FTIR study showed some of the bioactive compounds present in the T.natans extract like proteins, polysaccharides and phenolic compounds formed a strong coating on the biosynthesized silver nanoparticles.

\section{X-Ray Diffraction Analysis}

$\mathrm{XRD}$ is a powerful technology used for characterization of crystalline materials. ${ }^{16}$ The peaks of different nanoparticles formed show a characteristic pattern. XRD pattern obtained confirms the formation of nanoparticles. XRD of the AgNPs gave four characteristic peaks in the $2 \mathrm{~h}$ spectrum, which range from $20^{\circ}$ to $80^{\circ}$. The XRD spectrum pattern of dried T. natans AgNPs have shown distinct diffraction peaks at $2 \theta$ angles of $38.91^{\circ}, 45.73^{\circ}, 66.75^{\circ}$ and $79.89^{\circ}$ which can be indexed

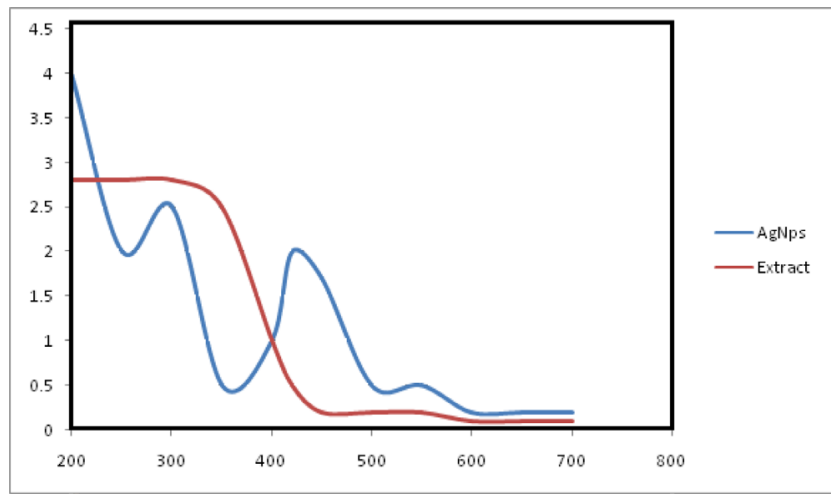

Figure 1: UV-Vis absorption spectrum of T.natans AgNPs and T.natans extract. 


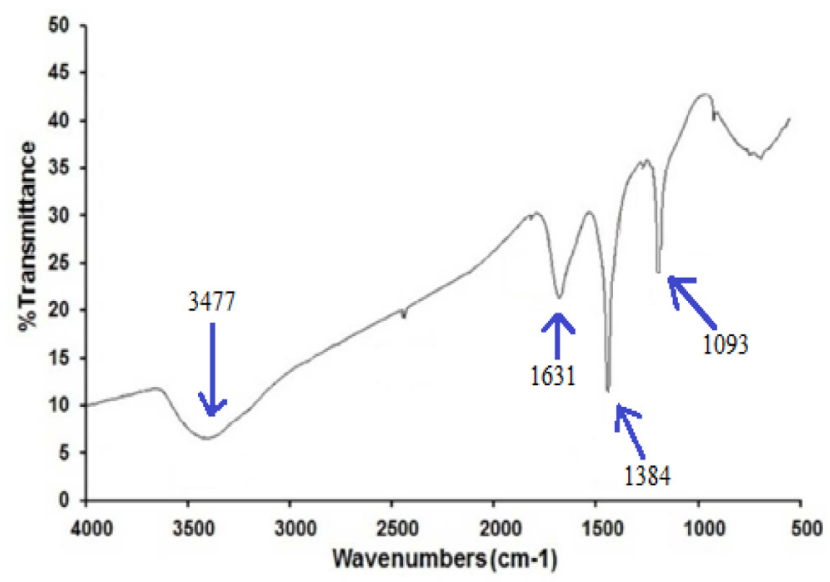

Figure 2: FTIR spectra of the biosynthesized silver nanoparticles from T.natans.

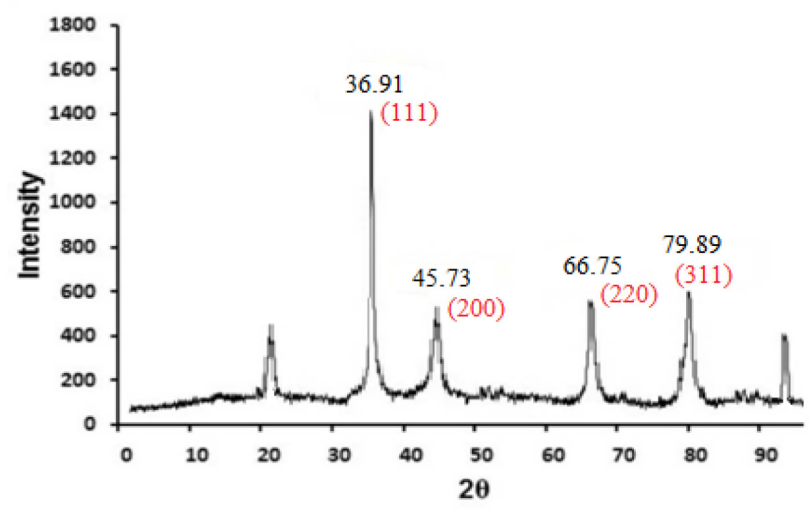

Figure 3: X-ray diffraction pattern of Trapa natans silver nanoparticles.

to the (111), (200), (220) and (311) Bragg's reflection of the face-centered cubic structure of silver crystals (Figure 3). Thus, the XRD results clearly demonstrated the silver nanoparticles formed in our experiment were highly crystalline in nature.

\section{SEM Analysis of Silver Nanoparticles}

The Scanning Electron Microscopy (SEM) technique was used to identify the morphology and size of the bioreducedAgNPs. The SEM image of T.natans-AgNPs is shown in Figure 4. The nanoparticles were almost spherical in shape with a narrow size distribution. The diameter of the silver particles was found to be in the range of 30-90 nm and a few particles were agglomerated due to the binding of some capping agents present in the T.natans extract or due to the particle aggregation in SEM measurement.

\section{TEM Analysis of Silver Nanoparticles}

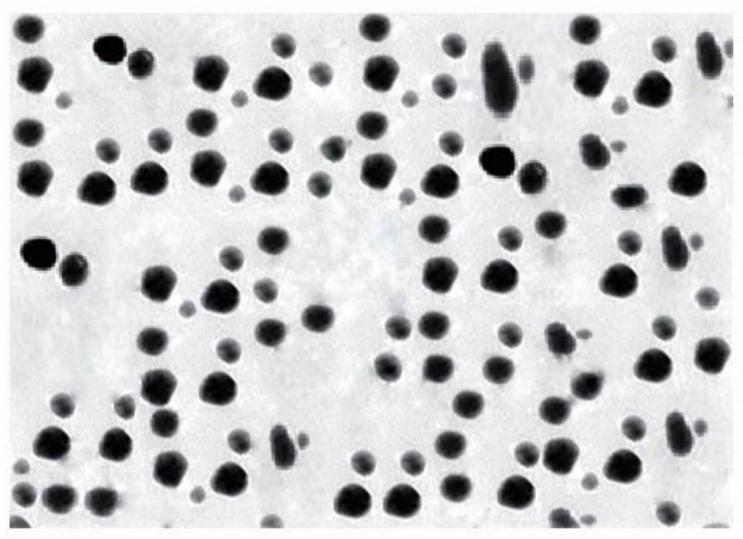

Figure 4: Scanning electron microscopy image of silver nanoparticles synthesized from T.natans.

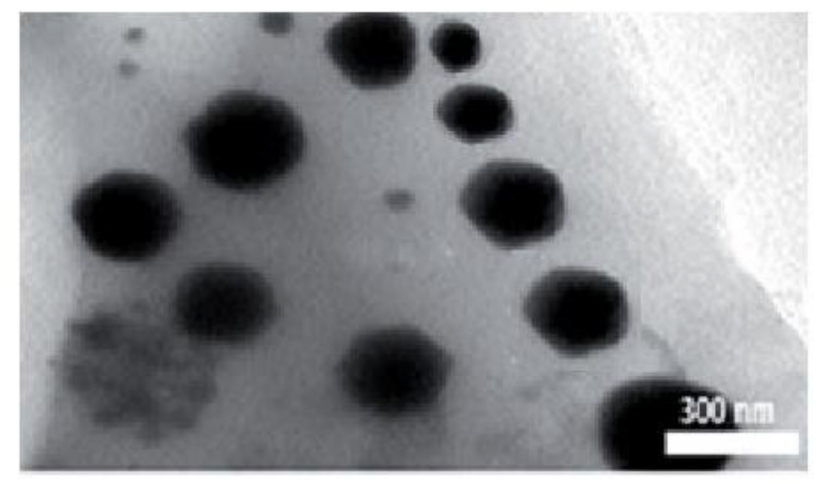

Figure 5:Transmission electron microscopy image of silver nanoparticles synthesized from T.natans.

The Transmission Electron Microscopy (TEM) image of synthesized AgNPs is depicted in Figure 5. The TEM image indicates that AgNPs are polydispersed particles and are mostly spherical in shape. The sizes of AgNPs were $15 \pm 2 \mathrm{~nm}$. With increasing concentrations, NPs became spherical.

\section{Cytotoxicity Analysis}

NPs are emerging as promising agents in cancer therapy due to their different physiochemical characteristics. ${ }^{17,18}$ Since metallic NPs have various features of metals, it has many advantages over simple plant extract. Earlier studies indicated that NPs smaller than $100 \mathrm{~nm}$ size could easily and efficiently enter into cells. ${ }^{19,20}$ To determine the potential of T.natans-AgNPs as therapeutic agents for the treatment of human breast cancer (MCF-7), their cytotoxicity were evaluated by MTT assay and neutral red uptake assay (NRU). The key results obtained by MTT and NRU assays in MCF-7 cells exposed to 


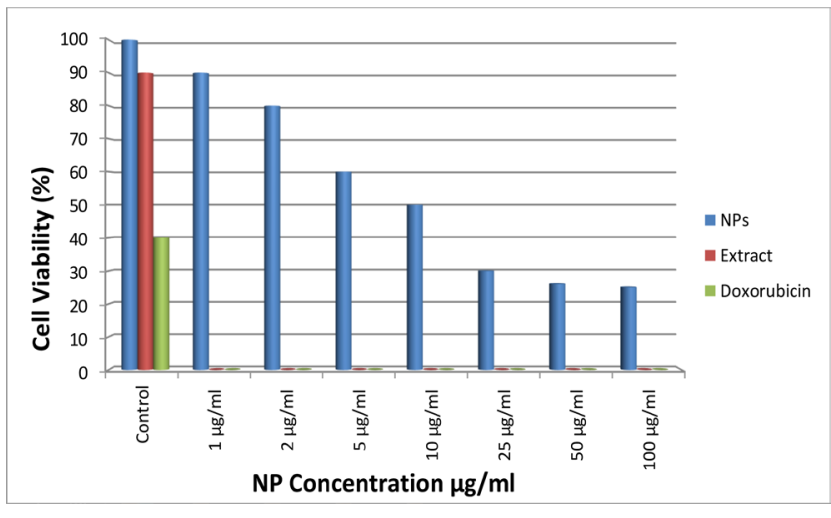

Figure 6(a):Effect of silver nanoparticles synthesized from Trapa natanscell viability of MCF-7 cells. Cells were treated with nanoparticles atvarious concentrations for $24 \mathrm{~h}$ and cytotoxicity was determined by theMTT assay.

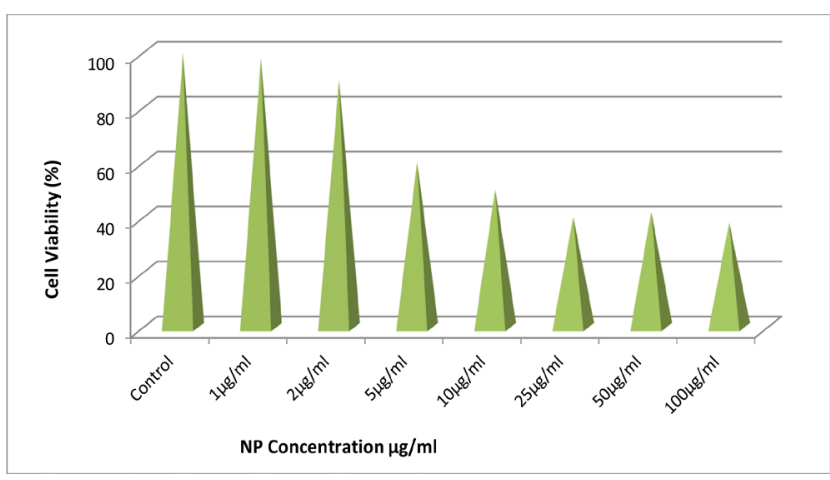

Figure 6(b):Effect of silver nanoparticles synthesized from Trapa natanscell viability of MCF-7 cells. Cells were treated with nanoparticles atvarious concentrations for $24 \mathrm{~h}$ and cytotoxicity was determined by theNRU assay.

$1 \mu \mathrm{g} / \mathrm{ml}$ to $100 \mu \mathrm{g} / \mathrm{ml}$ for $24 \mathrm{hr}$ are summarized in Figure 6(a) and 6(b). The results exhibit a concentration dependent decrease in the viability of MCF-7. However, at concentrations 25, 50 and $100 \mu \mathrm{g} /$ $\mathrm{mL}$ cell death increases. (Table 1 and Table 3) Incubation with AgNPs synthesized from T.natans at high concentration that is 25,50 and $100 \mu \mathrm{g} / \mathrm{ml}$, lead to a reduction in cell viability. Like MTT assay, a concentration-dependent decrease in cell viability of MCF-7 cells exposed to T.natans-AgNPs was also observed by NRU assay. The cell viability recorded at $100 \mu \mathrm{g} / \mathrm{ml}$ of T.natans-AgNPs shows maximum decrease in cell viability.

In this study, the cytotoxicity assessments were performed using two independent end points (MTT and NRU) assays. ${ }^{21}$ The MTT, a colorimetric assay is based on the mitochondrial dehydrogenase enzyme of viable cells; $; 2$ however, NRU assay is based on the lysosomal integrity of viable cells. ${ }^{23}$ The cytotoxic responses of the T.natans-AgNPs, suggesting that biosynthesized AgNPs

\begin{tabular}{|c|c|c|c|c|c|c|c|c|}
\hline & \multicolumn{8}{|c|}{ NP Concentration $\mu \mathrm{g} / \mathrm{ml}$ of AgNPs } \\
\hline & Control & $\begin{array}{c}1 \\
\mu \mathrm{g} / \\
\mathrm{ml}\end{array}$ & $\begin{array}{c}2 \\
\mu \mathrm{g} / \\
\mathrm{ml}\end{array}$ & $\begin{array}{c}5 \\
\mu \mathrm{g} / \\
\mathrm{ml}\end{array}$ & $\begin{array}{c}10 \\
\mu \mathrm{g} / \\
\mathrm{ml}\end{array}$ & $\begin{array}{c}25 \\
\mu \mathrm{g} / \\
\mathrm{ml}\end{array}$ & $\begin{array}{c}50 \\
\mu \mathrm{g} / \\
\mathrm{ml}\end{array}$ & $\begin{array}{c}100 \\
\mu \mathrm{g} \\
\mathrm{ml}\end{array}$ \\
\hline $\begin{array}{c}\text { Cell } \\
\text { Viability } \\
(\%)\end{array}$ & 100 & 90 & 80 & 60 & 50 & 30 & 26 & 25 \\
\hline
\end{tabular}

Table 2: The IC ${ }_{50}$ of T.natansAgNPs, T.natans Extract
and Doxorubicin. ${ }^{22}$
\begin{tabular}{|c|c|c|c|}
\hline Cell line & \multicolumn{3}{|c|}{ IC $_{50} \mu g / \mathrm{mL}$} \\
\hline & $\begin{array}{c}\text { T.natans } \\
\text { AgNPs }\end{array}$ & $\begin{array}{c}\text { T.natans } \\
\text { Extract }\end{array}$ & Doxorubicin \\
\hline MCF-7 & $26 \pm 3.14 \mu \mathrm{g} / \mathrm{mL}$ & $34 \pm 2.04 \mu \mathrm{gg} / \mathrm{mL}$ & $47 \pm 1.09 \mu \mathrm{g} / \mathrm{mL}$ \\
\hline
\end{tabular}

Notes: Values are expressed as Mean $\pm(S D=0.001)$ of three replicants

\begin{tabular}{|c|c|c|c|c|c|c|c|c|}
\hline & \multicolumn{8}{|c|}{ NP Concentration $\mu \mathrm{g} / \mathrm{ml}$ of AgNPs } \\
\hline & Control & $\begin{array}{c}1 \\
\mu \mathrm{g} / \\
\mathrm{ml}\end{array}$ & $\begin{array}{c}2 \\
\mu \mathrm{g} / \\
\mathrm{ml}\end{array}$ & $\begin{array}{c}5 \\
\mu \mathrm{g} / \\
\mathrm{ml}\end{array}$ & $\begin{array}{c}10 \\
\mu \mathrm{g} / \\
\mathrm{ml}\end{array}$ & $\begin{array}{c}25 \\
\mu \mathrm{g} / \\
\mathrm{ml}\end{array}$ & $\begin{array}{c}50 \\
\mu \mathrm{g} / \\
\mathrm{ml}\end{array}$ & $\begin{array}{c}100 \\
\mu \mathrm{g} / \\
\mathrm{ml}\end{array}$ \\
\hline $\begin{array}{c}\text { Cell } \\
\text { Viability } \\
(\%)\end{array}$ & 100 & 98 & 90 & 60 & 50 & 40 & 42 & 38 \\
\hline
\end{tabular}

could contribute in search of alternative chemotherapeutic agent. (Table 2) Our results showed more than $50 \%$ of cell death even at $5 \mu \mathrm{g} / \mathrm{ml}$ of T.natans-AgNPs. The cytotoxic effects induced by T.natans-AgNPs at lower concentrations could be due to the plant components attached to the AgNPs. ${ }^{24}$ The results obtained from this study are also very well supported with various evidences for the cytotoxic effect of biosynthesized AgNPs using T.natans peel extract against the breast cancer MCF-7 cell line.

\section{Determination of Intracellular Reactive Oxygen Species (ROS)}

The result obtained from ROS generation in MCF-7 cells exposed to T.natans-AgNPs for $24 \mathrm{hr}$ is shown in Figure 7.A statistically significant induction in ROS generation was measured in MCF-7 cells exposed to T.natans-AgNPs at $10,25,50$ and $100 \mu \mathrm{g} / \mathrm{ml}$ concentrations. The ROS levels generated in responses to AgNPs were significantly higher than in AgNPs treated cells than control. Nanoparticles are expected to induce their toxicity via oxidative stress by generating reactive oxygen species (ROS) involved in different cellular processes ranging from apoptosis and necrosis to cell proliferation and carcinogenesis. ${ }^{25}$ It has been documented that nanoparticles increase the ROS generation at cellular level. Taken together, all ofthese findings indicate that cell death is mediated by the production 


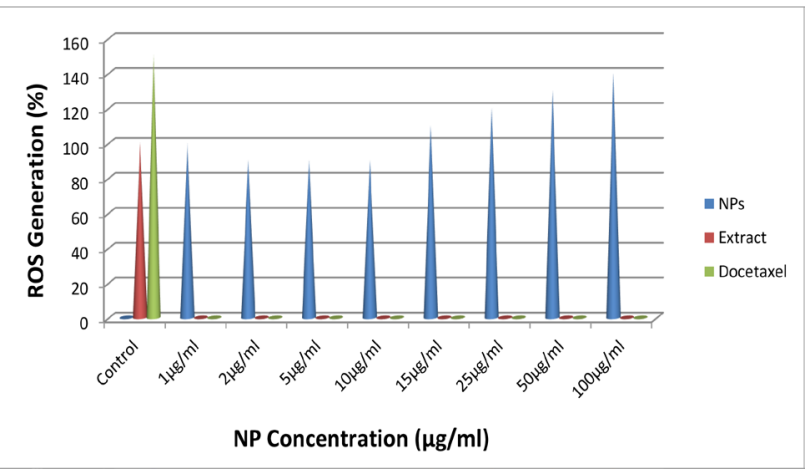

Figure 7:Reactive oxygen species generation in silver nanoparticles synthesized from Trapa natans treated MCF-7 cells.
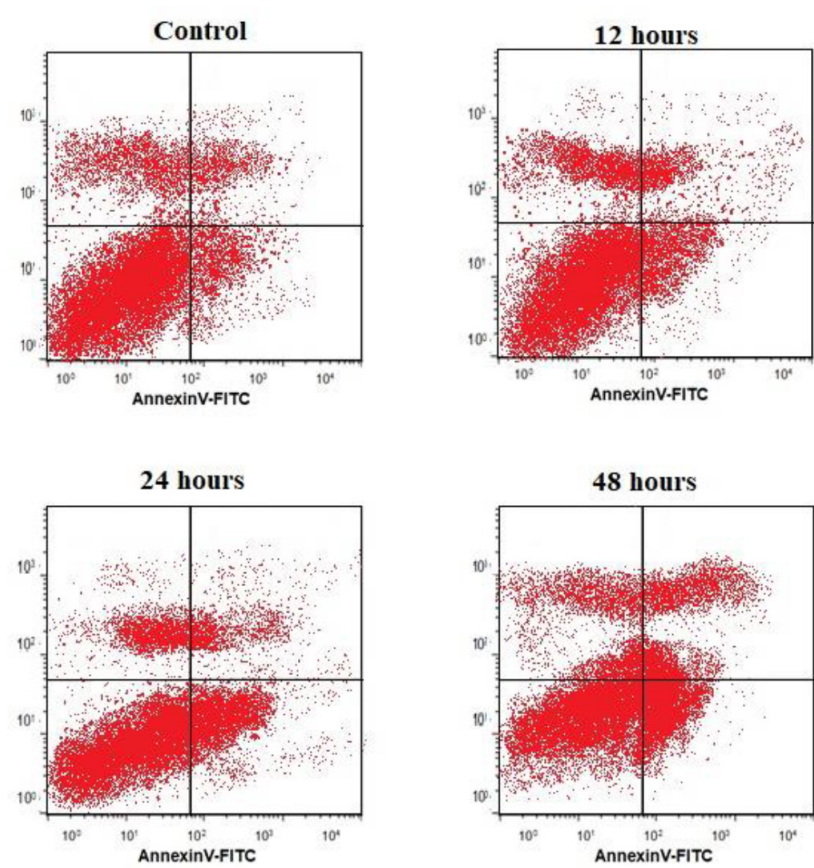

Figure 8: Annexin V-PE assay. The scatter plots show early apoptotic, late apoptotic and necrotic cells following 12, 24, $48 \mathrm{hr}$ treatment.

of ROS, which is likely to alter the cellular redox status and it is a potential cause for cell death.

\section{Apoptosis/Necrosis Assessment Using Annexin V}

Annexin-V/PI double-staining assay showed that MCF-7 cells treated with T.natans-AgNPs became apoptotic gradually, with concomitant decrease in viable cells in a time-dependent manner. After 12-h treatment, MCF-7 cells were primarily in the early phase of apoptosis and began to enter the late phase of apoptosis from $24 \mathrm{~h}$ onward. (Table 4) The results obtained from the induction of apoptosis/necrosis using flow cytometry are summarized in Figure 8. The MCF-7 cells exposed to T.natans-AgNPs

\begin{tabular}{|c|c|c|c|c|}
\hline \multirow[t]{2}{*}{ Cell Stage } & \multicolumn{4}{|c|}{ Cell \% } \\
\hline & Control & $12 \mathrm{hr}$ & $24 \mathrm{hr}$ & $48 \mathrm{hr}$ \\
\hline Viable & $94.4 \pm 0.35$ & $80.55 \pm 0.67$ & $78.25 \pm 0.25$ & $74.3 \pm 0.35$ \\
\hline $\begin{array}{c}\text { Early } \\
\text { Apoptosis }\end{array}$ & $5.55 \pm 0.75$ & $7.57^{*} \pm 0.95$ & $8.85^{*} \pm 0.35$ & $11.7^{*} \pm 0.45$ \\
\hline $\begin{array}{c}\text { Late } \\
\text { Apoptosis/ } \\
\text { Necrosis }\end{array}$ & $3.92 \pm 0.20$ & $8.85^{\star} \pm 0.95$ & $10.85^{*} \pm 0.75$ & $12.3^{*} \pm 0.20$ \\
\hline
\end{tabular}

Notes: Values are expressed as mean $\pm S D$ of triplicate experiments. Data has been analyzed using one-way ANOVA.

* indicates significant value $(P$ - 0.05) different from control.

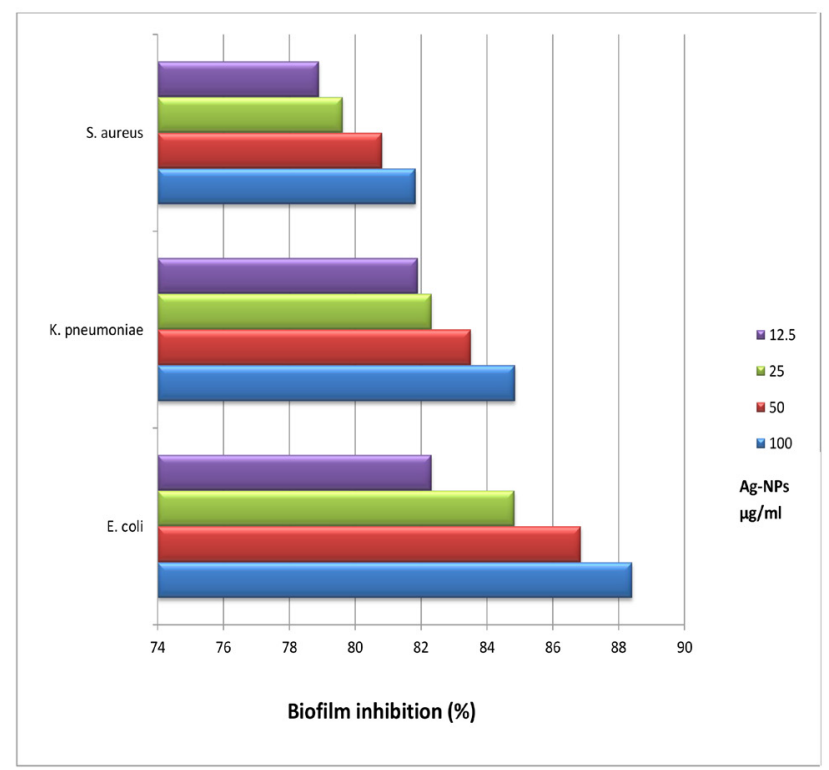

Figure 9: Anti-biofilm activity by using different concentrations $(12.5,25,50,100 \mu \mathrm{g} / \mathrm{mL})$ of silver nanoparticles synthesized from T.natans peel extract against different standard bacterial strains.

significantly increases the late apoptotic and necrotic cells as compared to untreated control cells. It is well known that high amount of ROS generation could lead to apoptotic and necrotic cell death. ${ }^{26}$ The excessive ROS generation has been linked with the substantial DNA damage and apoptosis/necrosis. ${ }^{27}$ Our results are consistent with the recent reports of apoptosis cell death due to the exposure of nanoparticles ${ }^{28}$ including the exposure to plant synthesized silver nanoparticles. ${ }^{29}$

\section{Antibiofilm Activity}

The results of tissue culture plate method indicates that antibiofilm activity of the biosynthesized AgNPs from T.natans peel extract was $82.32 \%$ for E. coli, $81.90 \%$ for Klebsiella pneumoniae, and 78.90\% for Staphylococcus aureus, respectively at $12.5 \mu \mathrm{g} / \mathrm{mL}$ (Figure 9 and Table 5). 


\begin{tabular}{|c|c|c|c|c|}
\hline \multirow[t]{2}{*}{ Bacteria } & \multicolumn{4}{|c|}{ Concentration of Ag-NPs $(\mu \mathrm{g} / \mathrm{ml})$} \\
\hline & $\begin{array}{c}12.5 \\
\mu \mathrm{g} / \mathrm{ml}\end{array}$ & $\begin{array}{c}25 \\
\mu \mathrm{g} / \mathrm{ml}\end{array}$ & $\begin{array}{c}50 \\
\mu \mathrm{g} / \mathrm{ml}\end{array}$ & $\begin{array}{c}100 \\
\mu \mathrm{g} / \mathrm{ml}\end{array}$ \\
\hline Escherichia coli & 82.32 & 84.84 & 86.86 & 88.42 \\
\hline Klebsiella pneumoniae & 81.90 & 82.32 & 83.52 & 84.86 \\
\hline Staphylococcus aureus & 78.90 & 79.62 & 80.82 & 81.84 \\
\hline
\end{tabular}

These findings indicate that the uptake of the biosynthesized T.natans-AgNPs may reduce the biofilm forming abilities of tested pathogens. Similar studies were documented as results of biofilm inhibition at $100 \mu \mathrm{g} / \mathrm{mL}$ AgNPs. ${ }^{30}$ In addition, the antibiofilm action of AgNPs has been attributed to the diffusion through biofilms imparting antimicrobial activity. ${ }^{31}$

\section{DISCUSSION}

Green synthesis of silver nanoparticles is a promising approach for overcoming the limitations of conventional physicochemical routes. Bio-molecular reducing agents present in plant extracts such as proteins, reducing sugars, alkaloids, terpenoids, and phenolic compounds act as reducing agents as well as capping agents for the synthesis of silver nanoparticles. ${ }^{32}$ However, depending on the applied green extract, the biological activity, or toxicity profiles of the green synthesized AgNPs may differ considerably. ${ }^{33}$ Therefore, the present study reported the green synthesis of silver nanoparticles using T.natans leaf extract and testing their anti-proliferative activity against human skin cancer cells. AgNPs have generated a great deal of interest in biomedical field due to their potential therapeutic effects for variety of diseases such as acquired immunodeficiency syndrome (AIDS), retinal neovascularization, various infectious diseases and cancers. ${ }^{34,35}$

N. Ahmad et al. reported the efficiency of green synthesized Ag-Au NPs using Trapa natans peel extract as a cytotoxic agent against HCT116, MDA-MB-231 and HeLa cells. Their results showed that, the biosynthesized Ag-Au NPs had a clear cytotoxic activity on cells. The anticancer activity of this biosynthesized $\mathrm{Ag}-\mathrm{Au}$ NPs was determined to be highly related to apoptosis induction in HeLa, HCT116, MDA-MB-231 cells through the significant increase in ROS production. In another study by M.M. Saber et al. they used leaf extract of Trapa natans plant to biosynthesize silver nanoparticles as an antitumor agent against A431 skin cancer cell line. Their results showed that the presence of different bioactive molecules in T.natans extract bond to AgNPs surface like glycosides, amino acids, flavonoids, and polyphenols as well as nano-sized silver particles may be responsible for anticancer activity of biosynthesized AgNPs.

In our study, T. natans-AgNPs exhibited strong cytotoxic activity against MCF-7 breast cancer cell line. The presence of different bioactive molecules in T.natans shows that, green synthesized AgNPs significantly inhibited proliferation of MCF-7 breast cancer cells by inducing apoptosis as well as antibiofilm activity using different bacterial colonies. UV-vis spectroscopy, FTIR, SEM, TEM and XRD techniques were used to characterization of biosynthesized particles.In UV-vis spectroscopy we found that AgNPs exhibit strong absorption peak in the 420-500 nm range due to Surface Plasmon Resonance. In FTIR analysis the functional groups are identified by distinct peaks and we found phenol ansalcohol compounds (at $3447 \mathrm{~cm}^{-1}$ ), carbonyl groups (at $1631 \mathrm{~cm}^{-1}$ ), alcoholic groups (at $1384 \mathrm{~cm}^{-1}$ ) and polysaccharides (at $1093 \mathrm{~cm}^{-1}$ ). In XRD, the results clearly demonstrated that AgNPs formed in our experiment were highly crystalline in nature. In SEM we found the diameter of AgNPs to be in the range of 30-90 nm and TEM depicts the size of AgNPs to be $15 \pm 2 \mathrm{~nm}$. We found the $\mathrm{IC}_{50}$ value of AgNPs $(26 \pm 3.14 \mu \mathrm{g} / \mathrm{mL})$, Extract $(34 \pm 2.04$ $\mu \mathrm{g} / \mathrm{mL})$ and Doxorubicin $(47 \pm 1.09 \mu \mathrm{g} / \mathrm{mL})$. Primarily MCF-7 cells after $12 \mathrm{hr}$ treatment were in early apoptosis phase and proceed to late apoptosis from $24 \mathrm{hr}$ onwards. This study showed that Trapa natans-AgNPs have the capacity of inducing apoptosis and necrosis cell death of MCF-7 cells. Trapa natans-AgNPs were also found to induce oxidative stress as observed by the increase in ROS level. Thus, our findings suggest the anticancer potential of biosynthesized Trapa natansAgNPs against human breast cancer cells and could play an important role in the development of new therapeutic agent for the treatment of cancer. The biologically synthesized particles exhibits antimicrobial effect and the inhibition of biofilm formation against E. coli (82.32\%), K. pneumonia (81.90\%) and $S$. aureus $(78.90 \%)$ at $12.5 \mu \mathrm{g} / \mathrm{mL}$ concentration of AgNPs. Hence our full investigation shows the biosynthesis of silver nanoparticles using Trapa natans plant and its anticancer with antibiofilm activities.

\section{CONCLUSION}

This investigation demonstrates the biosynthesis of silver nanoparticles (AgNPs) via reduction of silver ions using Trapa natans plant and its anticancer potential against human breast cancer (MCF-7) cells and also antibiofilm potentials against biofilms. Our results suggested that water chestnut extracts have antibiofilm 
and antiproliferative activities and can be utilized as effective and safe antioxidant sources. Our results showed that biosynthesized AgNPs (Trapa natans AgNPs) induced a concentration-dependent cytotoxicity in MCF-7 cells. The biologically synthesized particles also exhibited antimicrobial effect and the inhibition of biofilm formation against Escherichia coli, Klebsiella pneumoniae and Staphylococcus aureus.

Our findings indicate a cost-effective and eco-friendly approach for Trapa natans AgNPs synthesis which may support the development of potential biomedical applications and alternative therapy involving the design of new antibiofilm agents and multi drug resistance bacterial infections, and could be further developed as a template for other anti-cancer actions. Further characterization of their chemical composition, structure of the active compounds, and mechanism of antibiofilm and antiproliferative activity is required so that it can be used in fields of medicine, cosmetology and pharmacy.

\section{ACKNOWLEDGEMENT}

The authors are thankful to DST Inspire, New Delhi for their research grant. We are also grateful to Utkal University for providing all sorts of help during the research work.

\section{CONFLICT OF INTEREST}

The authors declare no conflict of interest.

\section{ABBREVIATIONS}

AgNPs: Silver Nanoparticles; FTIR: Fourier Transform Infrared Spectroscopy; XRD: X-ray Diffraction; SEM: Scanning Electron Microscopy; TEM: Transmission Electron Microscopy; MTT: 3-(4,5-dimethylthiazol-2-yl)-2,5-diphenyltetrazolium bromide; ROS: Reactive Oxygen Species.

\section{REFERENCES}

1. Pradhan D, Tripathy G, Pradhan RK, Pradhan S, Dasmohapatra T. A Review on cuminosides nanomedicine- Pharmacognostic approach to cancer therapeutics. JYP. Vol.8(2); 2016. P. 61-71. PMID PUBMED.

2. MannJ. Natural products in cancer chemotherapy: past, present and future. Nat Rev Cancer.2002;2(2):143-8. doi: 10.1038/nrc723,.

3. WHO. Available from: http://who.int/cancer/en/index.html[cited3/6/2021].

4. Ferlay J, Shin HR, Bray F, Forman D, Mathers C, Parkin DM. Estimates of worldwide burden of cancer in 2008: GLOBOCAN2008. Int J Cancer.2010;127(12):2893-917. doi: 10.1002/ijc.25516,.

5. Cragg GM, Grothaus PG, Newman DJ. Impact of natural products on developing new anti-cancer agents. Chem Rev.2009;109(7):3012-43. doi: $10.1021 /$ cr900019j
6. Alexis F, Pridgen E, Molnar LK, Farokhzad OC. Factors affecting the clearance and biodistribution of polymeric nanoparticles. MolPharm.2008;5(4):505-15. doi: $10.1021 / \mathrm{mp} 800051 \mathrm{~m}$

7. Mosmann T. Rapid colorimetric assay for cellular growth and survival: application to proliferation and cytotoxicity assays. Jlmmunol Methods.1983;65(1-2):55-63. doi: 10.1016/0022-1759(83)90303-4

8. Afzal H, Mohamed FA, MerajAK, SyedAP, FaheemA, SamiraA. Biosynthesized silvernanoparticle (AgNP) from Pandanus odorifer Leafextractexhibitsantimetastasis and anti-biofilm potentials. FrontMicrobiol.2019;10(8).

9. Sladowski D, Steer SJ, Clothier RH, Balls M. An improved MTT assay. J Immunol Methods.1993;157(1-2):203-7. doi: 10.1016/0022-1759(93)90088-o

10. Zhu H, He M, Bannenberg GL, Moldéus P, Shertzer HG. Effects of glutathione and $\mathrm{pH}$ on the oxidation of biomarkers of cellular oxidative stress. Arch Toxicol.1996;70(10):628-34. doi: 10.1007/s002040050321,.

11. Balasamy RJ, Ravinayagam V, Alomari M, Ansari MA, Almofty SA, Rehman S, Dafalla H, RubavathiMarimuthu P, Akhtar S, Al Hamad M. Cisplatin delivery, anticancer and antibacterial properties of Fe/SBA-16/ZIF-8 nanocomposite. RSC Adv.2019;9(72):42395-408. doi: 10.1039/C9RA07461A.

12. LewisK. Riddle of biofilm resistance. Antimicrob Agents Chemother.2001;45(4):999-1007. doi: 10.1128/AAC.45.4.999-1007.2001,

13. Kathiravan V, Ravi S, Ashokkumar S. Synthesis of silver nanoparticles from Melia dubia leaf extract and their in vitro anticancer activity. Spectrochim Acta A MolBiomolSpectrosc.2014;130:116-21. doi: 10.1016/j.saa.2014.03.107

14. Gomathi M, Rajkumar PV, Prakasam A, RavichandranK. Green synthesis of silver nanoparticles using Datura stramonium leaf extract and assessment of their antibacterial activity. ResourEfficTechnol.2017;3(3):280-4. doi: 10.1016/j.reffit.2016.12.005.

15. D'Souza L, Devi P, Divya Shridhar MP, Naik CG. Use of Fourier Transform Infrared (FTIR) Spectroscopy to Study Cadmium-Induced Changes in Padina Tetrastromatica (Hauck). Anal Chemlnsights. 2008;3. doi: 10.4137/117739010800300001.

16. Bunaciu AA, Udriştioiu EG, Aboul-Enein HY. X-ray diffraction: instrumentation and applications. CritRevAnalChem.2015;45(4):289-99. doi: 10.1080/10408347.2014.949616,.

17. Jain S, Hirst DG, O'sullivan JM. Gold nanoparticles as novel agents for cancer therapy. BrJRadiol.2012;85(1010):101-13. doi: 10.1259/bjr/59448833

18. Pradhan S, Pradhan D, Behera B. Antiproliferation activity of Ocimumgratissimumaqueous extract on human breast cancer MCF-7 cell line. World Journal of Pharmaceutical Research.2018;7(9):421-8.

19. Jiang W, KimBY, RutkaJT, ChanWC. Nanoparticle-mediated cellular response is size-dependent. NatNanotechnol.2008;3(3):145-50. doi: 10.1038/nnano.2008.30,.

20. Shang L, Nienhaus K, Nienhaus GU. Engineered nanoparticles interacting with cells: size matters. JNanobiotechnology.2014;12(5):5. doi: 10.1186/14773155-12-5,

21. Nogueira DR, Mitjans M, Infante MR, Vinardell MP.Comparative sensitivity of tumor and non-tumor cell lines as a reliable approach for in vitro cytotoxicity screening of lysine-based surfactants with potential pharmaceutical applications.IntJPharm.2011;420(1):51-8. doi: 10.1016/j. ijpharm.2011.08.020,.

22. Sladowski D, Steer SJ, Clothier RH, Balls M. An improved MTT assay. J Immunol Methods 1993;157:203-7.

23. Borenfreund E, Puerner JA.Short-term quantitative in vitro cytotoxicity assay involving an S-9 activating system.Cancer Lett.1987;34(3):243-8. doi: 10.1016/0304-3835(87)90173-x

24. Ali MA, Chen SM, Ying L, Al-Hemaid FM, Abou-Tarboush FM, Farah MA, et al. Silver Nanoparticles Synthesized from Adenium obesum leaf extract induced DNA damage, apoptosis and autophagy via generation of reactive oxygen species. Colloids and Surf B Biointerfaces.2016;141:158-69.

25. Debasish P, Bandana B, Shakti P, Adyasa S. Screening of cytotoxicactivity of hematite ( $\alpha-\mathrm{Fe} 2 \mathrm{O} 3$ ) nanoparticles from Butea monospermaon MCF-7cells. PharmacognRes.2020;12(3):260-6.

26. Foldbjerg R, Olesen P, Hougaard M, Dang DA, Hoffmann HJ, Autrup H. PVPcoated silver nanoparticles and silver ions induce reactive oxygen species, apoptosis and necrosis in THP-1 monocytes. ToxicolLett.2009;190(2):156-62. doi: 10.1016/j.toxlet.2009.07.009 
27. Pradhan S, Pradhan D, Tripathy G, Dasmohapatra T. SOCS3 Reverses multidrug resistance by inhibiting MDRI in mammary cell carcinoma, IJRSE. Vol.3(2); 2016.

28. Pan Y, Neuss S, Leifert A, Fischler M, Wen F, Simon U, Schmid G, Brandau W, Jahnen-Dechent W. Size-dependent cytotoxicity of gold nanoparticles. Small.2007;3(11):1941-9. doi: 10.1002/smll.200700378,.

29. Stroh A, Zimmer C, Gutzeit C, Jakstadt M, Marschinke F, Jung T, Pilgrimm H, Grune T. Iron oxide particles for molecular magnetic resonance imaging cause transient oxidative stress in rat macrophages. Free RadicBiolMed.2004;36(8):976-84. doi: 10.1016/j.freeradbiomed.2004.01.016

30. Kalishwaralal K, BarathManiKanth S, Pandian SR, Deepak V, Gurunathan S. Silver nanoparticles impede the biofilm formation by Pseudomonas aeruginosa and Staphylococcus epidermidis. Colloids Surf BBiointerfaces.2010;79(2):340-4. doi: 10.1016/j.colsurfb.2010.04.014,

31. Malaikozhundan B, VaseeharanB, VijayakumarS, SudhakaranR, GobiN Shanthini G. Antibacterial and antibiofilm assessment of Momordica charantia fruit extract coated silver nanoparticle. Biocatalysis and Agricultural Biotechnology.2016;8:189-96. doi: 10.1016/j.bcab.2016.09.007.

32. Yilmaz M, Turkdemir $H$, Kilic MA, Bayram E, Cicek A, Mete A, Ulug B. Biosynthesis of silver nanoparticles using leaves of steviarebaudiana. MaterChemPhys.2011;130(3):1195-202. doi: 10.1016/j. matchemphys.2011.08.068.

33. Ahmed S, Ahmad M, Swami BL, Ikram S. A review on plants extract mediated synthesis of silver nanoparticles for antimicrobial applications: a green expertise. JAdvRes.2016;7(1):17-28. doi: 10.1016/j.jare.2015.02.007,.

34. Yilmaz, M., Turkdemir, H., Kilic M.A., Bayram, E., Cicek, A., Mete, A., et al. Biosynthesis of silver nanoparticles using leaves of Stevia rebaudiana. Materials Chemistry and Physics. 2011; 130(3):1195-1202. DOI: 10.1016/j. matchemphys.2011.08.068

35. Zhang XF, Liu ZG, Shen W, Gurunathan S. Silver Nanoparticles: Synthesis, Characterization, Properties, Applications, and Therapeutic Approaches. IntJ MolSci.2016;17(9):1534. doi: 10.3390/ijms17091534,.

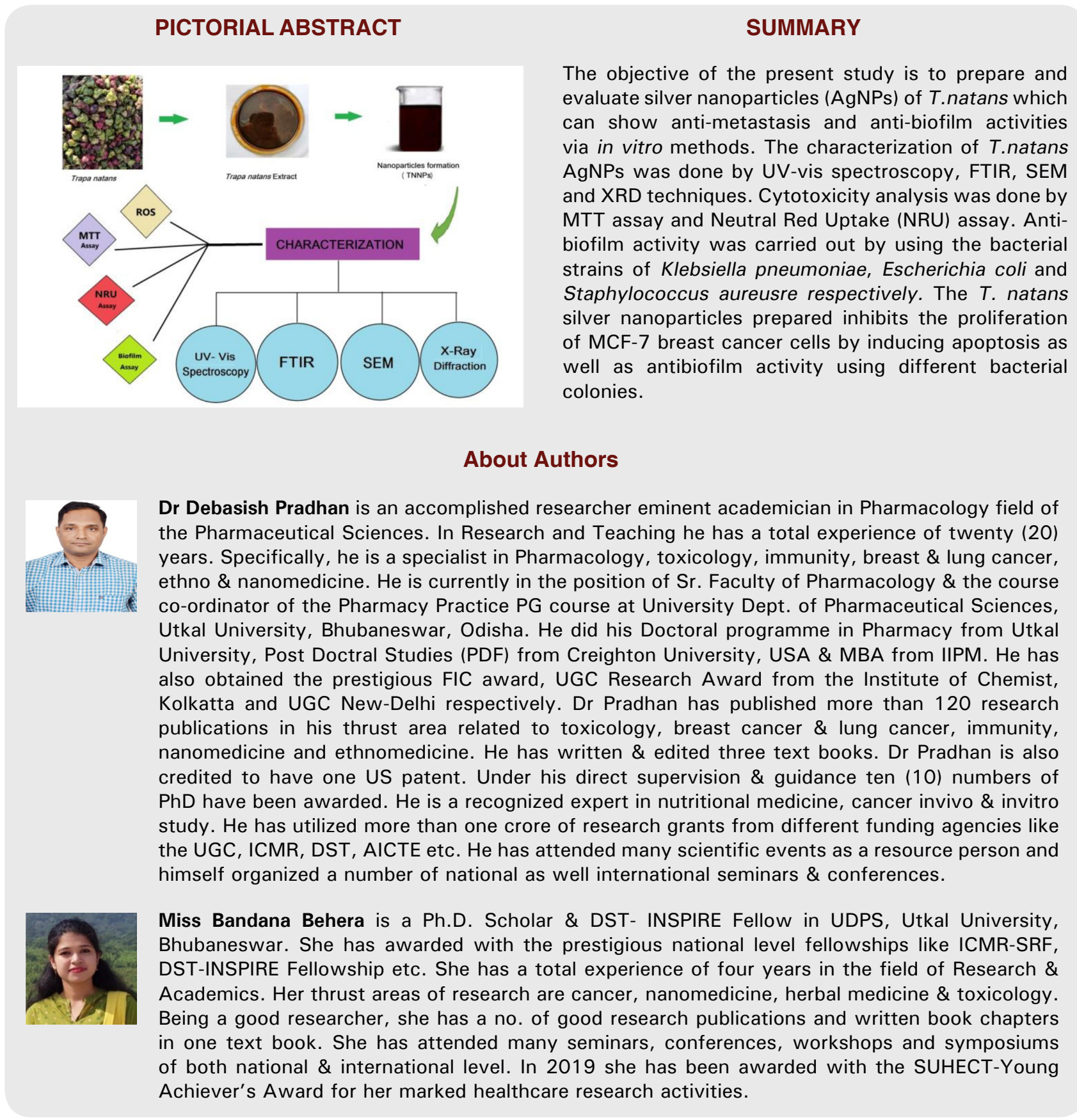


Miss Adyasa Samantaray, Research Scholar, UDPS, Utkal University. She has a number of research and review publications. Ironically, she possesses great skill in writing publication. She has attended many seminars and symposiums. Moreover, she has presented research papers in national and international seminars.

Cite this article: Samantaray A, Pradhan D, Behera B. Biosynthesized Silver Nanoparticles (AgNPs) from Trapa natans Peel Extract Exhibits Anti-Metastasis and Anti-Biofilm Potentials. Indian J of Pharmaceutical Education and Research. 2021;55(3):801-11. 